\title{
Batik Nitik's Existence in the Postmodern Era
}

\author{
Aida Roihana Zuhro ${ }^{1 *}$, I Ketut Sunarya ${ }^{2 * *}$, Wiga Nugraheni ${ }^{* * * *}$
}

Yogyakarta State University, Yogyakarta, Indonesia

*Corresponding Authors: aidda.rz@gmail.com

**Corresponding Authors: ketut_sunarya@uny.ac.id

***Corresponding Authors: wiga.heni23@gmail.com

\begin{abstract}
The visual form of a work of art is something that receives a lot of attention in the postmodern era. As a result, many works of art continuously experience development and upgrades that are adjusted to the artists' selfexpression. Nitik Batik is the oldest Batik style in Yogyakarta which has significantly developed in its visual form. This study aims to examine the existence of Nitik Batik in the postmodern era using a qualitative method and phenomenology approach. The research setting is in Bantul, Yogyakarta. Data were obtained through observations, interviews, and documentation. The analysis was done through data reduction, presentation, and drawing conclusions. The findings reveal that the existence of Nitik Batik in the postmodern era throughout the years can be summed up as follows: (1) from the function perspective, it can be used by all kinds of people; (2) from the motif perspective, the Nitik style has an overall of 60 motifs; (3) an association of Batik craftspeople was formed in 2017 by a group of women and young people as the next generation to preserve the existence of Batik Nitik; (4) the geographical indication has been registered at the Directorate of Brands and Geographical Indication as Batik with technical qualities based on the type of material, weaving technique, and recognition as the oldest Batik style in Yogyakarta.
\end{abstract}

Keywords: existence, Batik Nitik, motif, geographical indication

\section{INTRODUCTION}

Essentially, culture in its process is not static but is always dynamic in that there are always changes adjusted to the circumstances that occur in its formation. The belief of the people of Indonesia in understanding culture as heritage is not mistaken. Culture is considered as the archaic heritage which is vulnerable to refer to the spirit that is queuing towards culture because basically it indirectly contains a closed attitude and is interpreted as completed and static culture [4]. Culture should be interpreted as a "verb dimension" in which cultural heritage is an unfinished task but continuing now and in the future [4].

Batik is a form of culture, and it is an overall technique, technology, and development of related motifs and culture. Batik was designated by UNESCO as a Humanitarian Heritage for Oral and Non-material Culture (Masterpieces of Oral and Intangible Heritage of Humanity) since October 2009. From year to year, batik in Indonesia has continued to grow and change. In the postmodern era, this is a form of creativity that no longer has limits. Every work of art is subjective, as is the case with batik. The use of batik is not like in classical times, where various rules apply in its use. Nowadays, the use of batik is more flexible and can be found in various formal and non-formal events. Its development is also seen in the emergence of a variety of motifs, colors, manufacturing techniques, and materials used. The motifs developed are not immovable on classical ones, but more freely created in diverse forms such as the development of elements of traditional motifs, the sort of flora and fauna stylization in the surrounding environment, stories of daily life to expressive motifs creatively developed by its artisans.

Concerning this, Yogyakarta is one of the cities that is famous for its culture and batik, while some of its motifs are found there, like Parangkusumo, Pamulito, Truntum, Tambal, Sido Asih, Sido Mukti, Wahyu Tumurun and one of them is Nitik Batik. Nitik Batik is the oldest of its kind in Yogyakarta that captivates elements of Patola fabric from India. Lately, Nitik Batik has begun to experience quite a few developments, and the advance of increasingly diverse Nitik Batik motifs is a form of expression and creativity.

In this postmodern era, art is believed not to be a historical item or the thing of the past but reversely interpreted. In Lyotard's view, art as a quest that opposes the possibility of stability through representation. Likewise, Nitik Batik at present has experienced a number of developments tailored to the creativity and expression of its creators. Concerning this, the current paper aims to describe the shift in the function of Batik Nitik, specifically in the form of development of motifs and colors, as well as its existence in the postmodern era as the first-born batik in Yogyakarta.

\section{MeTHOD}

This study is qualitative descriptive research with research procedures to obtain results in the form of descriptive data or qualitative ones in social, cultural, religious, and philosophical description [1]. Qualitative research has the characteristics of natural research conditions where the main instrument is the researcher himself, obtaining descriptive data, emphasizing the process rather than results, directly 
displaying the purpose of the data, analyzing data since the beginning of the study, and analyzing data inductively [2]. The data from this research are the development and change of Nitik Batik in Bantul Regency, Yogyakarta Special Province obtained by observations, interviews, and documentation. Data analysis was performed through data reduction, presentation, and conclusion drawing following Miles and Huberman's view.

\section{DISCUSSION}

\section{A. Nitik Batik}

Compared with other batiks, Nitik Batik literally has a technical difference as its arrangement is in the form of a variety of ornamental lines and points that resemble a weave. Weaving motifs usually have a character that tends to symmetrically adjust between the thread and warp yarn in the process of making weaving [3]. Nitik decoration is influenced by Patola from India, which has the name "Cinde" in the Keraton (Palace) of Java. The emergence of Nitik Batik is possibly due to the high cost of Cinde cloth and its rarity, so that batik fabric is made with decorative styles like those of Cinde. Nitik Batik has been a favorite cloth in the palace as it is often used by the queens and nobles in certain events and is used by several Bedhaya Ketawang dancers (Bedhaya dances sacred in the palace of Yogyakarta).

The native Javanese people of Yogyakarta who still preserve the tradition of Nitik Batik live in the village of Trimulyo, Bantul Regency. The number of batik in Trimulyo is approximately 50 in types and each is created in the houses of these occupants. Aminah, one of the villagers, explained that the expertise in making batik from the people of Trimulyo village is possibly inherited, just as she obtained her expertise from her mother, Ibu Prengilah. In 2008, Abdul Syukur was one of the activists of Nitik Batik in the Trimulyo area, and he created several groups of Nitik Batik which are still growing. Abdul Syukur also has a Nitik Batik Studio situated in Kalipucang Hamlet, Neighborhood (RT) 04 Bangunjiwo Village, Kasihan District, Bantul Regency, named Batik Taman Lumbini.

Another distinctive feature of Nitik Batik that does not exist in other batik lies in that there is no patterning process on the fabric. The cloth to be Nitik Batik is only given diagonal lines of $3 \times 3 \mathrm{~cm}$ in size and the motif is directly produced from the hot wax applied in the form of lines and dots that form a motif, as seen in Fig. 1.

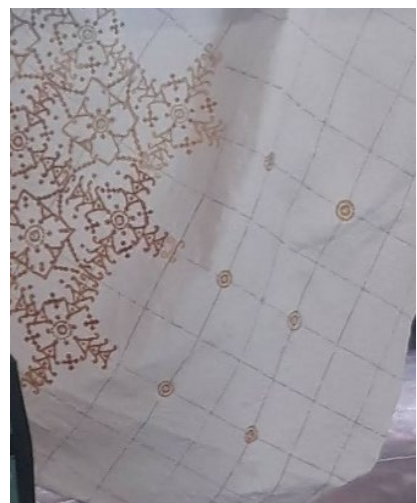

Fig. 1. The Nitik Batik Making on Unpatterned Fabric Source: Documentation of Kelompok Usaha Bersama

$(K U B)$

In general, the spouted tool used for wax-resist dyeing or canting used is different from that used in other non-printed or handmade batik. Canting used in making Nitik Batik is called canting cawing which is quite different from the regular canting, having a customized spout with four corners splayed outwards, allowing the hot wax to form a dot-shaped square. Each square is produced from every drop of canting cawang. The process of making canting cawing is presented in Fig. 2.
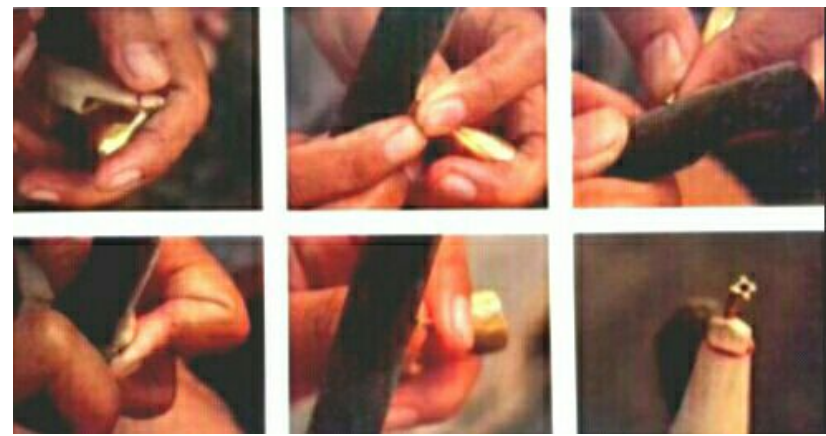

Fig. 2. Canting Cawang Creating Process Source: Revealing Nitik Patterns in Wastra Batik

\section{B. The Shift of Nitik Batik Function}

Yogyakarta has four types of large batik motifs, namely Parang, Semenan, Ceplok, and Nitik. Nitik batik is included in the motif of batik considered to have the highest level of difficulty because it is a combination of dots so that its manufacturing process is longer than that of the other four big motifs originated from Yogyakarta.

Besides being included in the great motifs of Yogyakarta's batik, Nitik batik used to be only used for the descendants of the palace community at certain events, for example, the Nitik cloth with the motif of chicken claws formerly used for wedding ceremonies. The position of a work of art in the form of batik in classical times is believed to be integrated with all activities of people's daily life, having a general character of the symbolic art because what is captured is not only what appears but also the inner energy behind it, or the meaning contained within [7]. 
As time goes by, in the postmodern era, meaning and philosophy have possibly been put aside. Currently, batik can be used by everyone, from the elite, noble population, to the ordinary people. Nowadays, people choose to wear batik not due to its philosophical meaning but for its desirable visible motifs. In the postmodern era, everyone has a subjective opinion, triggering the possibility of assessing a work of art only from its visibility to the eye on its surface. Presently batik is one of the workmanships that can be expressed without limits. In terms of function, it is more flexible and can be used as a costume, decoration, and even a souvenir of widespread trips as its motifs can now be printed on a variety of media other than textiles.

Previously, Javanese society was identical to Javanese culture, Javanese aristocratic culture, but in the current postmodern era, the status of batik has probably changed. One reason for this may be the cultural contact in Indonesia for a long period of time accompanied by the fading of the patron. Postmodern society is now characterized by an urban society, meaning that batik currently belongs to all groups, including the posterities of the palace community and Javanese nobility, and the grassroots, even it no longer belongs to the Javanese, but the entire Indonesian nation.

\section{The Development of Nitik Batik Motifs}

Beforehand, Nitik Batik motifs first developed on the north coast of the Java sea, starting from a merchant from Gujarat sailing on the north coast of the Java island carrying woven fabric with Gujarat silk material as one of the merchandises. The woven fabric has a geometric motif with a double tie technique known as Patola. This cloth has red and green colors, and in Java, Patola is known as Cinde cloth. Based on this design, there came the idea of batik artisans from the coastal area, the interior, and the palace to make a batik with woven motifs that resembled Patola and were called Nitik Batik with dotted lines, several points, and other variations like the fabric [8]. Nitik Batik is categorized into 6 groups, namely nitik; nitik and cecek; nitik and klowong; nitik, cecek, and klowong; nitik, klowong and tembokan; and nitik, cecek, klowong and tembokan category. This categorization is based on the canting used. For example, if nitik batik motifs are included in the nitik and cecek category, they are crafted by means of nitik canting and cecek canting.

Until now, there are 60 kinds of nitik batik motifs that possibly will continue to grow in the postmodern era. As with Lyotard's opinion, postmodernism is a system of openness that allows art to open its indeterministic diversity. Postmodernism presents multiple realities and many alternatives [5]. This opinion strengthens the condition of nitik batik in the postmodern era today where it has diverse motifs that can continue to be developed without any restrictions as there is no right wrong and everyone has the right to judge the beauty of nitik batik subjectively. It is also in accordance with the view of postmodernism in which truth becomes a subjectivity and the position of science in this era is an expansion of dissimilar views (subjectivism) and clarifies the attitude of tolerance to incomparable views [6].

Similarly, in the past nitik batik had certain standards where its motifs had philosophical meaning and the colors used tended to use soga brown (a warm brown color ranging from a light yellowish tan to a deep chocolate brown depending on the mordant used), dark blue, black-blue, and black. This is understood as a cultural heritage that must be preserved to date. The main point is that preserving culture is not a static process, and its changes should be adjusted to the conditions of the times. This is a form of culture that is always dynamic in which culture should be inspired as a "verb dimension", meaning that culture, especially cultural heritage, is an unfinished task, continuing in the present and the future which is currently in the postmodern era. Culture formed and developing gradually in accordance with the conditions shows that it still exists and is timeless [4].

Post-modernism is characterized by several thoughts about art from the past and is characterized by the mixing of art, society, and tradition as nowadays art functions both socially and personally. One form of the development of batik in Yogyakarta in the postmodern era is in terms of techniques, media, and motifs. In terms of techniques, batik not only develops handmade drawing techniques, but also holds the stamping, painting, and even electric canting connected to CNC. In terms of media, the materials used are also diverse, not only involve loth but also cover wood or vegetable-tanned leather. In terms of motifs, now it can be developed to suit the wishes of the batik manufacturers. This is in accordance with the postmodern era where arts has a broad meaning as an effort to re-create things and stratagem for changing life to be more harmonized with humanity's highest and deepest aspirations. Whereas in the narrow sense, arts refers to the diversity of creativity in forms and images, in order to sharpen their effects on sensibility and sensation and to relax reflective and taste awareness [7].

Although the postmodern era is believed to be the fusion of all kinds of arts, there are no boundaries, and the heart and imagination can develop at liberty. Citizens of Indonesia that are rich in culture, therefore, can create positive energy while preserving what should be preserved without limiting the expression and creativity of each individual. If Observed, especially in nitik batik, there are two main points, the first is to consider batik as a cultural heritage that must be preserved and the second is batik as a culture that must be continued and developed in accordance with the times because in truth there is no finish for a work of arts. These two points become the primary basis in recognizing, maintaining, and continuing batik, especially nitik batik in this era. For example, in the village of Trimulyo, batik has sprung up in accordance with the creativity of each batik artisans in that it cannot be generalized. This must be continuously developed and explored as the job of successors to nitik batik of the era.

The new face of nitik batik is starting to emerge in terms of a more diverse coloring, combining several nitik motifs, combining nitik batik with the stylization of the surrounding flora, and many more processes. This process can be regarded as conservation of the postmodern era's batik. Batik conservation is carried out in the form of innovative development in making creative and innovative nitik batik in accordance with the wishes of its creators. The term "nitikan" batik can be said to be the result of the development of a nitik batik motif or to be the descendant of a nitik batik (Java: tiron, putran). In the postmodern era like today, the use of the name nitikan batik is based on the suffix "an" which means the development of classical batik which still refers to nitik batik in order to continue to exist with its characteristics as the oldest batik in Yogyakarta. 
What should be underlined is the concept of nitikan batik which still refers to nitik batik and it does not intend to limit the desire of postmodern batik craftsmen who wish to produce nitikan batik. Rather, it explains what is called Nitik Batik in the terminology is that batik has a technical difference where the motifs are arranged by shattered lines or dots. Therefore, in this postmodern era, the development of motifs can be tailored to the wishes and concepts of its creators with an arrangement of cracked lines and dots. In accordance with the explanation where culture must be positioned as a "verb dimension", Nitik batik cannot be said as a finished cultural heritage. Even in classical times, the motifs possibly always experience developments and changes in these days until some of them could be called classical batik. Thus, the concept of development and change will always be in every culture.

Nitikan batik can also be called a batik creation that suits to the concept of postmodern arts where the artworks is always directed and refer to itself (autotelic). The development of nitikan batik which refers to nitik batik today depends on how its artisan expresses his/her ideas personally, no longer bound by the grip or philosophy but the motifs remain composed of a combination of lines and dots webbed as the special characteristic from nitik batik. This is why in the era of postmodernism this such batik remains more wide-ranging and still exists.

One manifestation of nitik batik conservation more commonly referred to as nitikan batik found in the village of Kembangsongo, Bantul, Yogyakarta is carried out by a local resident named Mrs. Aminah - cloth with a background of typical Balinese Poleng motif (woven black-and-white checkered textile). Nitik Batik which is rich in motifs indirectly explains that its motifs still exist and are recognized throughout Indonesia as the oldest batik in Yogyakarta. The following is one form of development of Yogyakarta Nitik Batik.

Nitikan Batik with a combination of some nitik motifs was developed by Mrs. Aminah by making a combination of nitik batik motifs on one cloth, and the dyes used were replaced with synthetic ones with the dominant color of soga brown so that despite its developments, philosophically it still refers to the parent culture. The nitik motif used is the integration of Sekar Srengenge, Sekar Ceplok, Sekar Jeruk, Sekar Gedhe and Sekar Kenanga on one nitik batik cloth. Fig. 3 presents nitik batik motifs before they were developed:

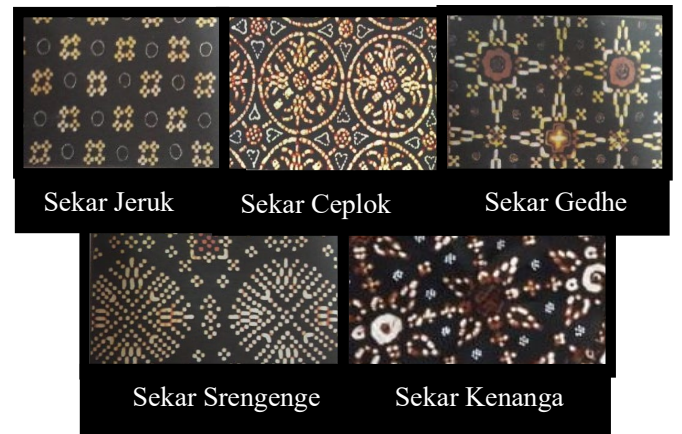

Fig. 3. The Classic Motifs of Nitik Batik Source: "Kumpulan Motif Batik" Book
The picture explains the classic nitik batik that has not yet been developed, while the forms of development of the classic motif are presented in Fig. 4

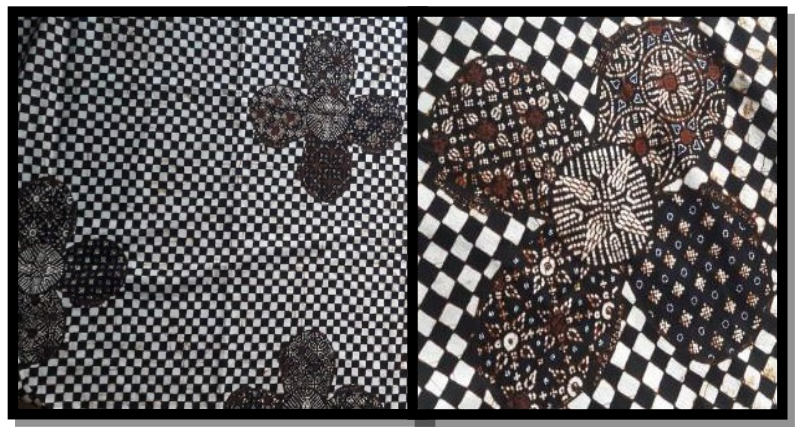

Fig. 4. "Kembang" Nitikan Batik

Source: Documentation of Batik Trimulyo

Another example of nitikan batik development is also found in Taman Lumbini Batik Studio. The difference of the development here is the combination of the stylization of the peony flower motif, as presented in Fig. 5.

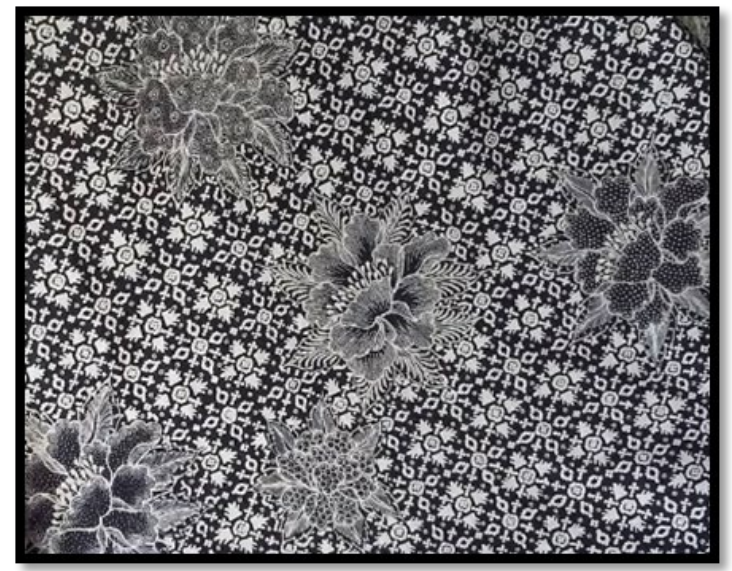

Fig. 5. Peony Nitikan Batik

Source: Documentation of Studio Batik Taman Lumbini This kind of nitikan batik is the evidence of the preservation of cultural heritage and coupled with the emergence of a new face of nitik batik that is tailored to personal creativity so that nitik batik which is believed to be a cultural heritage is still unfinished and continues to develop as a form of indigenous culture of Indonesia in its era. The picture is part of an example of the development of Nitik Batik in terms of motifs that have begun to emerge in accordance with the expression and creativity of batik creators. Although it currently has a lot of development in terms of both motifs and coloring processes, what needs to be emphasized is that the dynamics of nitik batik as the oldest batik in Yogyakarta until the emergence of nitikan batik proves that nitik batik still exists and can make one proof that there is still a form of preservation and the development of a cultural heritage in the form of nitik batik that appears in accordance with postmodern times this.

\section{$D$. The Existence of Nitik Batik}

Existence comes from the word "exist", which means coming out of overcoming or overcoming with dynamic processes [9]. 
Likewise, though batik nitik is the oldest batik in Yogyakarta until now it has been experiencing development. This is proven by the community in Trimulyo Village who have a long tradition of making batik for generations.

In 2008, Abdul Syukur began to foster the people of Trimulyo Village to develop nitik batik to be better known. Considering in the era of the kingdom of Mataram, the village was the first place for the emergence of nitik batik. The tradition of making batik in Trimulyo Village is carried out in their homes by residents who are dominated by mothers. At present, there are several batik communities in the Trimulyo area, one of which is the Sekar Nitik Batik Association. Wagirah explained that batik activities in the Kembangsongo area have become a routine for her and some of the village mothers since she was a teenager. Nitik batik manufacturing skills are believed to have been hereditary. In addition to the Sekar Nitik Association, there is also the Nitik Batik Association of the Kelompok Usaha Bersama (KUB) or the Joint Business Group, which was chaired by Mrs. Puji Hariyati with a total of around twenty members. The latter association was founded in 2017 and has several routine activities carried out within a certain period, namely collective batik making and regular meetings scheduled according to the Javanese calendar.

\section{1) Collective batik making}

The activity of collective batik making of the KUB in Trimulyo Village is carried out routinely once a week on Friday. Located in the yard of the house of Ibu Puji, the residents of Trimulyo, the activity is dominated by mothers, gathering while bringing their own batik. The process of batik making usually starts in the morning around eight until one o'clock in the afternoon. This has become a routine carried out for the last two years since the community was founded. The purpose of the association is to facilitate nitik batik craftsmen meetings to gather and create new nitik motifs and to develop the batiking skills of Trimulyo young generations as potential successors of batik craftsmen so that nitik batik can still be known and exist in the Trimulyo village and in Yogyakarta. In addition to this Friday batiking, the residents of Trimulyo Village each day also make their batik at their homes. Besides being a daily tradition in the village of Trimulyo, batik has become the livelihood of some people in the village.

\section{2) Routine meetings scheduled according to the Javanese Calendar}

KUB meetings are routinely held every Thursday. Each of the meetings is all about reflection and evaluation of the development of the community and plans to introduce nitik batik to the public, one of which includes diligently making it exhibited at several important events in Yogyakarta. Besides, the evidence of the existence of Nitik batik can be seen in the efforts of registering the geographical indication (GI) of Nitik batik by batik lovers in Yogyakarta, namely Sekar Jagad Batik on July 26, 2019. GI represents a recognition or sign of the origin of works of art and products supported by geographical and environmental factors such as natural factors, human factors, and the collaboration of both factors.
Nitik batik registering involving geographical indications grounds at its uniqueness in terms of dots created by using cawang canting resulting in fabric made by weaving techniques recognized as the oldest batik in Yogyakarta developed in Trimulyo, Bantul, Yogyakarta. In the future of nitik batik is expected to be known by the world as one of the oldest batik in Yogyakarta with its several uniqueness, as can be found directly in Trimulyo, Bantul, as the geographical indication of nitik batik.

\section{Conclusion}

Nitik batik has technical differences when compared to other batiks. Its arrangement takes the form of a variety of ornamental lines, and points that resemble weave. It is believed to be included in the batik motif which is considered to have the highest level of difficulty because it is a combination of dots so that the process takes longer than the other 4 big motifs originating from Yogyakarta. The status of batik has now become the property of all groups o people, not only descendants of the Yogyakarta palace and Javanese nobility or its common people, but also the entire Indonesian nation.

In this postmodern era, Nitik Batik develops 90 motifs initiated from plant diversity in the Yogyakarta region and possibly these motifs have had some development. This is in line with the principle that post-modernism is characterized by the thoughts of art in the past and focuses on the integration of works of art with society and tradition meaning that arts have social and personal functions.

One form of the development of Yogyakarta batik in the post-modern era is the one that can be said to be the conservation of Nitik Batik which produces Nitikan Batik. This is evidence of the preservation of cultural heritage and coupled with the emergence of some new faces of Nitik Batik tailored to personal creativity. Thus, Nitik Batik which is believed to be a cultural heritage is still continuing to develop as a form of indigenous culture in accordance with the era. One of the examples is combining some Nitik motifs and other motifs on one cloth and joining them with some techniques and stylization of several plants. Although Nitik Batik currently has some development in terms of both motifs and coloring process, the point that needs to be underlined is that its dynamics as the oldest batik in Yogyakarta until the emergence of Nitikan Batik proves that this type of arts still exists is preserved, and developed as a cultural heritage.

As revealed in the study, the people of Trimulyo Village are involved in batik making every day in their homes. Besides being a day-to-day tradition in the village of Trimulyo, batiking is an activity that becomes the livelihood of some people in the village. There are several communities of Nitik Batik in the area, for example, the Sekar Nitik Batik Association and the Nitik Batik KUB that have held their routine activities since their members were teenagers. Some of these associations have regular events for the Nitik Batik artisans to gather and create new Nitik motifs. They also have an ideal goal, namely to foster 
village youngsters as successors of Nitik batik artisans who develop their village to be central of Nitik Batik.

Besides, another proof of Nitik Batik existence can be seen from batik lovers' efforts in Yogyakarta, Sekar Jagad Batik, on the registering the Geographical Indication (GI) of Nitik Batik on July 26, 2019, as batik which has its uniqueness in terms of techniques resulting in fabric having done with weaving techniques and as the oldest

\section{REFERENCES}

[1] Bogdan, Robert, \& Steven J. Taylor. Introduction to qualitative research methods: A phenomenological approach to the social sciences. John Wiley \& Sons, (1975).

[2] Endraswara, Suwardi. "Metodologi Penelitian Posmodernisme Sastra [Research Methodology of Literary Postmodernism]." Yogyakarta: CAPS (2016).

[3] Fathurrahman, Sunarya, et al. "Batik Tembe Renda: Straightening Out Misconception about Culture." International Conference on Art and Arts Education (ICAAE 2018). Atlantis Press, (2019). DOI: https://dx.doi.org/10.2991/icaae-18.2019.9

[4] Kasiyan. "Perspektif Postmodern dan Postkolinial dalam Dialektika Kajian Pluralitas Seni dan Budaya Global [Postmodern and Postcolonial Perspectives in Dialectics Study of Global Plurality of Art and Culture].'Jurnal Pendidikan Seni Rupa. Universitas Negeri Yogyakarta. (2003). batik in Yogyakarta originating from Trimulyo, Bantul, Yogyakarta. The future expectation of these people is that the whole world knows more about Nitik Batik as one of the oldest batik in Yogyakarta with several uniqueness found directly in Trimulyo, Bantul as Nitik Batik's GI.

[5] Lyotard, Jean-François. The postmodern condition: A report on knowledge. Vol. 10. U of Minnesota Press, (1984).

[6] Maksum, Ali. "Pengantar Filsafat: Dari Masa Klasik Hingga Postmodernisme. [Introduction to Philosophy: From Classical to Postmodernism]" Yogyakarta: Ar-Ruz Media (2008).

[7] Sugiharto, Bambang. "Untuk apa seni? [What Is Art for?]. Matahari, (2013). URL: http://hdl.handle.net/123456789/978

[8] Susanto, Sewan. "Seni Kerajinan Batik Indonesia [Indonesian Batik Art]." Yogyakarta: Balai Penelitian Batik dan Kerajinan, Lembaga Penelitian dan Pendidikan Industri, Departemen Perindustrian R.I. 1973.

[9] Abidin, Zainal. "Memahami Manusia Melalui Filsafat [Understanding Humans through Philosophy]." Bandung: Remaja Rosdakarya (2006). 